\title{
ВЕНЧУРНИЙ КАПІТАЛ ТА ІННОВАЦІї
}

\author{
Непран А. В., канд. екон. наук, доцент \\ Харківський національний автомобільно-дорожсній університет \\ Тимченко I. С., канд. екон. наук, доцент \\ Харківський університет
}

Постановка проблеми. У зв'язку із спадом виробництва та погіршенням економічної ситуації в Україні велике значення набувають інструменти і засоби підвищення конкурентоздатності національної економіки. Перехід на інноваційний тип економічного розвитку передбачає створення сприятливих умов для структурних перетворень в області науково-технічного розвитку. Це, зокрема, потребує створення багатоканальної системи фінансування інновацій. Зростаюча увага до сфери науки, інноваційного підприємництва, ризикового бізнесу особливо актуальна в сучасних умовах, коли нові технології (надчиста металургія, мікроелектроніка, біотехнологія, нанотехнологія та ін.) потребують тісної інтеграції науки з виробництвом, ведуть до суттєвому зростанню витрат на розробку нового продукту при зростаючому скороченні його життєвого циклу. Все це потребує пошуку нетрадиційних каналів фінансування інноваційної діяльності, виробітку нової стратегії менеджменту інновацій.

Важливу роль у фінансуванні інноваційної діяльності відіграє такий унікальний механізм, як венчурний (ризиковий) капітал. Він служить засобом прискорення розвитку науково-технічного прогресу завдяки новим формам диверсифікації, міжфірмового співробітництва і кооперації, неграційним джерелом фінансування в умовах хронічного зростання фіктивного капіталу.

Розвиток венчурного капіталу, його залучення в Україну для фінансування перспективних інноваційних проєктів здатний не лише прискорити інноваційний розвиток країни, а й вивести вітчизняну економіку на новий рівень економічного розвитку. Венчурний капітал через систему фінансування інноваційних проєктів 3 високим потенціалом зростання призводить до створення кумулятивного ефекту: розвиток технологій в одній сфері призводить до прогресивного руху в інших сферах $\mathrm{i}$ секторах національної економіки.

Аналіз останніх досліджень і публікацій. Теоретичне обгрунтування розвитку венчурного капіталу в Україні знайшло відображення в працях багатьох вітчизняних вчених, зокрема О. Амоши, В. Савченко, I. Грозного, В. Красовської, Т. Смовженко, В. Новікової, Л. Дмитриченко, К. Кутрань, Н. Краус, Л. Шило та ін. Аналізуючи ринок інститутів спільного інвестування, до якого відносяться й венчурні фонди, Л. Бражник робить висновок: «Порівняно зі світовим досвідом ринок інституціональних інвесторів небанківського сектору перебуває на досить низькому рівні» [1, с. 280]. 
Досліджуючи структуру активів венчурних компаній, Є. Носова робить висновок, що венчурні фонди не зацікавлені здійснювати додаткові інвестиції в акції понад необхідний рівень в $10 \%$, та, насправді, використовуються для оптимізації фінансування та оподаткування фінансово-промислових груп [2]. Серед основних напрямів удосконалення організації венчурного фінансування в Україні О. Третякова, В. Харабара, Р. Грешко називають створення податкових стимулів і правового поля для індивідуальних інвесторів, які беруть участь у венчурному фінансуванні інноваційних компаній на початкових етапах комерціалізації новацій [3, с. 23].

Серед основних факторів, що стримують розвиток венчурного капіталу в Україні, Т. Кочура відносить недосконалість нормативно-правового регулювання венчурного інвестування та оподаткування, відсутність державної допомоги венчурним фондам при інвестуванні ними ризикових інноваційних проєктів [4, с. 123]. Проте в свої дослідженнях автор не наводить жодних доказів даного твердження. Оскільки венчурні інвестиції характеризуються великим ризиком, стає незрозумілим, чому держава повинна допомагати венчурним фондам і хто буде компенсувати збитки? Згідно з позиції автора, держава за рахунок бюджету повинна спрямовувати значні (не зрозуміло в якому обсязі) фінансові ресурси 3 невідомою їх ефективністю. Ми не розділяємо позицію автора, оскільки це призведе лише до нецільового використання бюджетних коштів, корупції та збільшенню дефіциту державного бюджету.

Невирішені складові загальної проблеми. Проте слід зазначити, що у вітчизняній економічній літературі недостатня увага приділяється формуванню капіталу венчурними фірмами. Більшість дослідників зазначають недостатні обсяги фінансування венчурними фондами інноваційних проєктів національної економіки. Не зважаючи на значні зміни податкового законодавства, спрямувати венчурний капітал для фінансування інноваційних проєктів в значних масштабах не вдається. Практично відсутні наукові розробки, що аналізують одночасно формування i використання капіталу венчурними фондами.

Формулювання цілей статі. Мета статті - проаналізувати поточний стан розвитку венчурного капіталу в Україні і запропонувати механізми залучення венчурного капіталу для підвищення конкурентоздатності української економіки.

Виклад основного матеріалу досліджень. Відповідно до Стратегії розвитку сфери інноваційної діяльності на період до 2030 року цілями довгострокового розвитку $є$ впровадження в Україні європейських стандартів життя та вихід України на провідні позиції у світі [5]. Сдино можливим засобом досягти вказаних цілей довгострокового розвитку України є перехід економіки до інноваційного соціально-орієнтованої моделі розвитку.

Прискорення науково-технічного процесу, що визнаний в усьому світі в якості важливого фактору економічного зростання, пов'язується із становленням та розвитком особливої сфери діяльності - інноваційного 
підприємництва. Цей вид діяльності полягає в отримані нововведень i простягається від зародження ідеї до їі комерційної реалізації, охоплюючи таким чином весь комплекс відносин: виробництво, обмін, споживання. Впровадження інновацій розглядається бізнесом не як самоціль, а як засіб кращого рішення виробничих і комерційних задач компанії, яка хоче досягти максимізації прибутку. Цей бізнес характеризується підвищеним ступенем ризику, високими темпами розвитку і незвичною гнучкістю, необмеженими адаптаційними можливостями. Завдяки залученню венчурного капіталу до фінансування інноваційного підприємництва були створені такі корпорації, як HP, Microsoft, Apple, Oracle, Yahoo, Google, Intel.

Розвиток інноваційної діяльності обслуговується унікальним механізмом фінансування, рухомою пружиною якого виступає обіг венчурного (ризикового) капіталу. Для інноваційного підприємництва венчурне фінансування $є$ одним із перспективних інструментів фінансового забезпечення, що дозволяє компенсувати «розриви» між фінансовими потребами та наявними коштами молодих інноваційних фірм, які ще не досягли точки беззбитковості. При чому венчурне фінансування не лише вирішує завдання залучення фінансових ресурсів для інноваційної діяльності, але $\epsilon$ одним із засобів відбору найбільш якісних інвестиційних проєктів, які мають значні перспективи зростання.

Приступаючи до розробки та комерціалізації нововведень, компанії повинні починати з авансування грошового капіталу. Суттєва специфіка такого роду вкладень полягає в тому, що вона пов'язана з різко підвищеною загрозою їх втрати: інновації носять високий ступінь ризику i невизначеність у відношенні до майбутньої норми прибутку. Іншими словами, віддача від вкладення капіталу в інноваційний проєкт має дуже мало спільного 3 гарантованими виплатами проценту на банківський депозит або дивіденду на акції.

Фінансування за рахунок венчурного капіталу має суттєві відмінності від традиційного банківського кредитування. Інноваційний фонд венчурного фінансування по відношенню до фірми, що впроваджує інновації, виконує роль донора. Фінансова компанія скуповує у знов створеної інноваційної фірми більшу частину ii пакету акцій. При набуття достатнього розміру та кредитоспроможності підприємство може бути продане стратегічному інвестору або бути виведеним на організований фондовий ринок. Ефективна діяльність інноваційної фірми гарантує фонду венчурного капіталу багаторазове перевищення від первісної суми вкладеного капіталу, тобто цей процес поновлюється на розширеній основі. Звичайний термін венчурної інвестиції складає 3-5 років. На практиці найнижчими 3 точки зору ефективності вважаються венчурні інвестиції в компанії, які за п’ять років забезпечують десятикратне зростання капіталу.

Як відомо, впровадження інновацій в нові, наукомісткі галузі зіштовхується 3 безпрецедентним ризиком. Лише десята частина крупних технічних проєктів стає рентабельними. Для більшості невеликих підприємств 
банківське кредитування та фондовий ринок недоступні. Цю нішу займає фонди «ризикового» фінансування. Таким чином, венчурний капітал приймає на себе значний ризик, виступаючи партнером фірми-інноватора. В свою чергу, венчурна організація ділить ризик серед багаточисленними партнерами пропорційно вкладу кожного із них. Для оцінки успішності інноваційного проєкту венчурна фірма повинна мати достовірну інформацію про всі напрямки інноваційної діяльності, зміни кон'юнктури ринку, мати тісні зв'язки із менеджерами інших галузей економіки. Інакше досить складно оцінити успішність того чи іншого інноваційного проєкту.

Венчурні фонди спільно 3 інноваційними компаніями розробляють графіки проєктних робіт, вирішують проблеми збуту продукції, здійснюють підбір кадрів, проводять експертизу, патентний аналіз. Венчурні фонди, таким чином, створюють сприятливе середовище, в якій «проростають» перспективні наукові нововведення. Саме ці організації стали одними із провідних структурних ланок поширення в розвинених країнах так названих інкубаторів бізнесу. В них діє пільгове оподаткування, широко поширене венчурне фінансування, надаються численні посередницькі послуги: проведення технічної експертизи, патентний аналіз, комерційні розрахунки, маркетинг, інформаційне забезпечення, управлінське консультування, ліцензування і т. п.

Структура венчурного капіталу відрізняється різноманітністю та складністю. При всій чисельності (починаючи із внутрішніх «венчурів»у структурі великих фірм і закінчуючи науково-технічними консорціумами). обов'язково дві складові: інноваційні дослідницькі фірми і загальний фонд венчурного фінансування.

В Україні ринок венчурного капіталу став формуватися в 1990-х роках. Правові та організаційні основи створення та діяльності венчурних фондів в Україні визначено в Законі Україні «Про інститути спільного інвестування» [6]. Основними задачами венчурного капіталу $\epsilon$ мобілізація підприємницької діяльності, забезпечення фінансування інноваційних компаній і перетворення їх в конкурентоспроможні компанії, які володіють великим потенціалом зростання і капіталізації бізнесу.

За останні десять років венчурний капітал в Україні стрімко розвивався. Чисельність венчурних фондів зросла 31035 в 2016 р. до 1292 в 2020 р. Нарощування кількості венчурних фондів після спаду 2016 р. є позитивним явищем, що означає посилення конкуренції в даному сегменті ринку. Вартість активів венчурних фондів, незважаючи на погіршення ділової активності, продовжує зростати (табл. 1).

Тенденція зростання активів венчурних компаній була характерною для періоду з 2012 по 2015 рр. В 2015 р. темпи приросту основних показників венчурного капіталу знизилися, а починаючи 32016 р. на фоні стагнації економіки, був зафіксований суттєвий спад на венчурному ринку України. Капітал венчурних компаній в 2016 р. скоротився до 221,3 млрд грн, що нижче показника 2015 р. на 4,7 \%. 
Динаміка активів венчурних компаній та підприємств промисловості за 2016 - 2020 рр.

\begin{tabular}{|l|c|c|c|c|c|}
\hline \multicolumn{1}{|c|}{ Показники } & 2016 p. & 2017 p. & 2018 p. & 2019 p. & 2020 p. \\
\hline Венчурний капітал, млрд грн & 221,3 & 256,1 & 289,4 & 331,6 & 407,4 \\
Темп зростання, \% & 95,3 & 115,7 & 113,0 & 114,6 & 122,9 \\
Активи промисловості ${ }^{1}$, млрд грн & 2790,4 & 3142,6 & 3431,9 & 3639,0 & 3346,5 \\
Темп зростання, \% & 115,5 & 112,6 & 109,2 & 106,0 & 92,0 \\
Відношення венчурного капіталу & & & & & \\
до ВВП, \% & 9,3 & 8,6 & 8,1 & 8,3 & 9,7 \\
\hline
\end{tabular}

1 За 2020 р. обсяг активів промисловості включає великі та середні підприємства.

Джерело: Показники балансу підприємств за видами економічної діяльності за відповідні роки / Державна служба статистики України. URL: http://www.ukrstat.gov.ua/; Звіт Національної комісії 3 цінних паперів та фондового ринку за відповідні роки / Національна комісія з циінних паперів та фондового ринку. URL: https://www.nssmc.gov.ual

Починаючи з 2017 р. венчурний капітал знову став стрімко зростати, перевищивши на кінець 2020 р. 400 млрд грн. В цілому за 2015-2020 рр. обсяг венчурного капіталу зріс на 175,2 млрд грн, або на 75,5 \%. Проте зростання венчурного капіталу були дещо нижчими порівняно із темпами зростання капіталу в промисловості.

Діяльність держави, професійних національних та іноземних учасників ринку при звели до становлення в Україні ринку венчурного фінансування. В останні роки повільне відновлення української економіки і нестабільна ситуація на фондовому ринку сприяли укріпленню тенденції до зростання ролі фондів «ризикового» капіталу.

Зростаючи масштаби обсягів венчурного капіталу дозволяє розглядати ринок венчурного фінансування в якості одного із найбільш ефективних та значущих інструментів для стимулювання зростання інноваційної економіки. Інноваційні фонди ризикового капіталу акумулюються на акціонерних началах із багатьох джерел: капітал корпорацій, банківських кредитів, пенсійних фондів та страхових компаній.

Незважаючи на те, що за 10 останніх років 3 моменту прискореного розвитку ринку венчурного фінансування в Україні була створена законодавча база, повністю сформувати систему ринку в цілому (як важливий інструмент розширеного відтворення фінансового капіталу) поки не вдалося.

В Україні спостерігається тенденція до зростання ролі венчурного капіталу на первинному ринку цінних паперів. Формування венчурного капіталу відбувається переважно за рахунок емісії цінних паперів. Обсяг зареєстрованих емісій цінних паперів інститутів спільного інвестування (ICI) становив на кінець 2020 р. 530,4 млрд грн. Особливо зросла роль венчурного капіталу на первинному ринку цінних паперів в 2020 р. (табл. 2). 
Таблиия 2

Обсяги емісії цінних паперів інститутів спільного інвестування 3a 2016-2020 pp.

\begin{tabular}{|c|c|c|c|c|c|}
\hline Показники & 2016 & 2017 & 2018 & 2019 & 2020 \\
\hline $\begin{array}{lll}\text { Обсяг зареєстрованих } & \text { випусків } \\
\text { інвестиційних сертифікатів } & \text { пайових } \\
\text { інвестиційних фондів } & \end{array}$ & 5,37 & 6,26 & 5,94 & 12,95 & 5,05 \\
\hline $\begin{array}{c}\text { Обсяг зареєстрованих випусків акцій } \\
\text { корпоративних інвестиційних фондів }\end{array}$ & 10,72 & 13,71 & 16,60 & 24,98 & 38,52 \\
\hline $\begin{array}{l}\text { Емісія цінних паперів ICI, млрд грн } \\
\text { Питома вага емісії цінних паперів ICI в } \\
\text { загальному обсязі емісій цінних } \\
\text { паперів, \% }\end{array}$ & 16,09 & 19,97 & 22,54 & 37,93 & 43,57 \\
\hline
\end{tabular}

Докерело: Звіт Національної комісії з цінних паперів та фондового ринку за відповідні роки / Начіональна комісія з иінних паперів та фондового ринку. URL: https://www.nssmc.gov.ual

Як свідчать дані, обсяг емісії цінних паперів ICI зріс з 16,09 млрд грн в 2016 р. до 43,57 млрд грн, або в 2,7 рази. Найбільше зростання обсягів емісії цінних паперів спостерігалося в 2019 р. (15,4 млрд грн). Основними формами емісії цінних паперів виступали емісія інвестиційних сертифікатів та емісія акцій. За 2016-2020 рр. обсяг емісії інвестиційних сертифікатів знизився на 6,0 $\%$, тоді як обсяги емісії акцій зросли в 3,6 рази. В результаті емісія акцій стала основною формою первинної емісії ICI на ринку цінних паперів. Якщо у 2016 р. частка акцій в загальному обсязі емісії цінних паперів ICI склала 66,6 \%, тоді як у 2020 р. вона зросла до $88,4 \%$.

Починаючи з 2018 p. ICI та їх домінуючий вид - венчурні компанії - на первинному ринку цінних паперів стали відігравати все зростаючу роль. В 2020 р. на їх долю приходилося 38,4 \% від загального обсягу емісії цінних паперів, тоді як у 2016 р. - 7,3 \%. Зростання части емісії ICI відбулося переважно за рахунок скорочення обсягів емісії іншими учасниками ринку, перш за все підприємствами реального сектору економіки.

Впровадження інноваційно-інвестиційної моделі розвитку національної економіки $є$ можливими лише за умови максимального використання й якісного оновлення науково-технологічного потенціалу. В сучасних умовах інновації $\epsilon$ засобом виживання підприємства в конкурентній боротьбі. Проте сучасний рівень інноваційної діяльності не дає змогу розраховувати на прискорений інноваційний розвиток. Так, в 2020 р. питома вага інноваційної продукції в промисловому випуску становила 1,9 \% проти $1,4 \%$ у 2015 р. У зв'язку із спадом ділової активності, викликаною макроекономічною нестабільністю, обмеженістю джерел фінансування і невизначеністю у відношенні до ключових макроекономічних показників інноваційна активність українських підприємств залишається на низькому рівні.

Стримуючим фактором розвитку інноваційного підприємництва в Україні $\epsilon$ недостатній обсяг фінансування. Проте в країні складається парадоксальна 
ситуація. 3 однієї сторони, відсутність значних довгострокових ресурсів у підприємств на реалізацію інноваційних проєктів, 3 іншої сторони - великі ресурси грошового капіталу, які є у розпорядження суб'єктів фінансового ринку. Зокрема, на сьогоднішній день венчурні компанії мають в достатній мірі грошовий капітал для фінансування інноваційної діяльності. Цей висновок підтверджується даними табл. 3.

Таблиия 3

Співвідношення витрат на інноваційну діяльність та венчурного фінансування

\begin{tabular}{|l|c|c|c|}
\hline \multicolumn{1}{|c|}{ Показники } & 2018 p. & 2019 p. & 2020 p. \\
\hline $\begin{array}{l}\text { Приріст вапіталу венчурного } \\
\text { фінансування }{ }^{1} \text {, млрд грн }\end{array}$ & 33,31 & 42,12 & 75,82 \\
\hline Витрати на інноваційну діяльність, млрд грн & 25,02 & н.д. & 23,33 \\
\hline $\begin{array}{l}\text { Відношення венчурного фінансування до } \\
\text { обсягів витрат на інноваційну діяльність }\end{array}$ & $1,33: 1$ & - & $3,25: 1$ \\
\hline
\end{tabular}

Джерело: Витрати на інновачії за видами економічної діяльності / Державна служба статистики України. URL: http://www.ukrstat.gov.ua/; 3вim Національної комісії з цінних паперів та фондового ринку за відповідні роки / Національна комісія 3 иінних паперів та фондового ринку. URL: https://www.nssmc.gov.ual

На українському інвестиційному ринку в теперішній час маються значні обсяги фінансових ресурсів, які можуть бути спрямовані в сегмент венчурного фінансування. Обсяг фондів венчурного капіталу значно перевищує обсяги витрат на інноваційну діяльності. Так, у 2020 р. співвідношення венчурного фінансування до витрат на інноваційну діяльність становило $3,04: 1$, тобто за обсягом венчурний капітал майже в 3 рази перевищував обсяг витрат на інноваційну діяльність. Таким чином, маючи значні фінансові ресурси, венчурні компанії не інвестують їх в інноваційні проєкти.

У розвинених країнах венчурні інвестиції здійснюються переважно в ризикові, технологічно і потенційно високодохідні (проєкти з прогнозованою внутрішньою нормою дохідності IRR не менше 15 \%) проєкти. При цьому під інвестиціями венчурної компанії розуміється купівлю акціонерного (установчого) капіталу не публічної компанії-реципієнта інвестицій або надання довгострокового боргового (до 5 років) фінансування 3 можливістю конвертації часток або акцій. Найбільш перспективними сферами вкладення венчурного капіталу $є$ інноваційні проєкти, які володіють високим рівнем ризику втрати коштів.

При посередництві венчурного бізнесу в Україні постійно зростали обсяги фінансування як в нові галузі, так і в традиційні галузі національної економіки, де раніше венчурний капітал не приймав участі у фінансуванні. Змінюються переваги венчурних інвесторів до більшої ліквідності і меншому ризику. Почалася його експансія в традиційні сфери фінансової діяльності - 
деривативи, державні цінні папери та облігації внутрішніх місцевих позик (табл. 4).

Таблиия 4

Приріст активів венчурних фондів України в 2019-2020 рр., млн грн

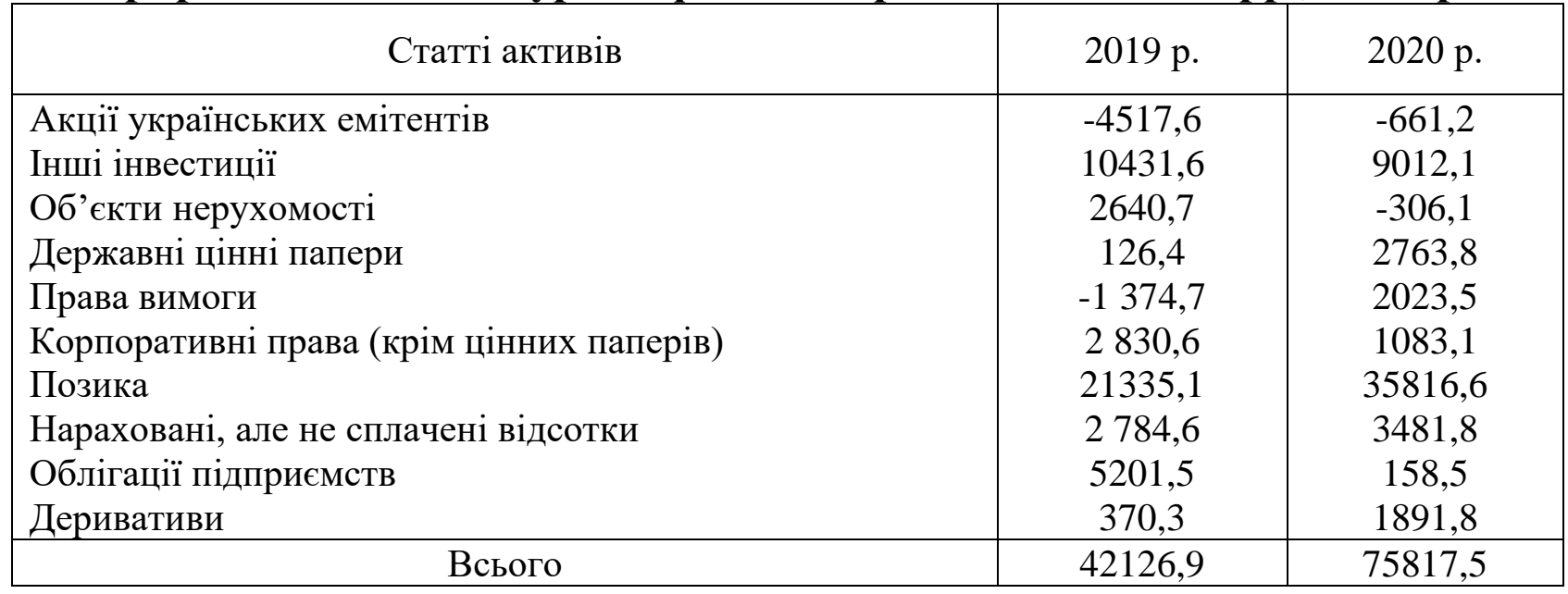

Джерело: Звіт Національної комісії з цінних паперів та фондового ринку за відповідні роки / Національна комісія з изінних паперів та фондового ринку. URL: https://www.nssmc.gov.ua/

Тривалий час пріоритетним напрямом вкладення додаткового венчурного капіталу тривалий час $є$ надання позик. В 2020 р. обсяг коштів, наданих позичальникам, становив 35,8 млрд грн, що становить 47,2 \% від загального обсягу приросту капіталу венчурних фондів. Як наслідок, станом на кінець 2020 р., загальний обсяг позик в активах венчурних фондів досяг 141,7 млрд грн, що становить 34,8 \% від загального обсягу їх активів.

В 2019 р. суттєво зростали обсяги вкладень в об'єкти нерухомості, облігації підприємств. В 2020 р. відбулася зміна пріоритетів вкладень додаткового капіталу. Починаючи з 2020 р. венчурні фонди значні фінансові ресурси вкладали в державні цінні папери (на 2763,8 млн грн), в деривативи (1891,8 млн грн), а також в облігації місцевих позик (на 206,1 млн грн). В той же час спостерігається тенденція до скорочення інвестицій в акції - основний вид цінних паперів венчурних фондів.

Досліджуючи напрямки діяльності найбільших венчурних фондів України, Є. Носова прийшла до висновку, що більшість 3 них використовуються як інструмент спільних інвестицій та оптимізації оподаткування в будівельному, фінансовому та аграрному секторі [2].

Отже, в Україні значна частина венчурного капіталу використовується для фінансових вкладень, не пов'язаних із інноваційною діяльності. Це, передусім, надання позик суб'єктам господарювання, вкладення капіталу в державні цінні папери, облігації внутрішніх місцевих позик, об'єкти нерухомості, банківські метали та ін.

Такий механізм інвестування венчурного капіталу, пов'язаний iз диверсифікацією ризиків, нагадує самострахування, коли інвестори захищають 
себе від значних фінансових втрат. Які ж причини такої ситуації? Розглянемо це питання детальніше.

В Україні реалізовані ряд заходів податкової підтримки інноваційної діяльності. Зокрема, фонди венчурного капіталу в Україні наділені унікальними преференціями в сфері оподаткування. Податковим кодексом (пп. 141.6.1 ст. 141) передбачено, що інститути спільного інвестування, до яких відносяться венчурні фонди, звільняються від оподаткування кошти спільного інвестування, а саме: доходи від здійснення операцій з активами інституту спільного інвестування, доходи, нараховані за активами інституту спільного інвестування, та інші доходи від діяльності інституту спільного інвестування (відсотки за позиками, орендні (лізингові) платежі, роялті тощо) [7]. Як відзначали Діденко Л. та ін., завдяки цьому передбачається здійснення реінвестування коштів фонду на беззбитковій основі [8, с. 145]. Оподаткуванню підлягає лише розподіл прибутку, тобто виплата дивідендів. Суттєві податковими преференціями користуються фізичні особи-інвестори, податкове навантаження на дивіденди від ICI становить $10,5 \%$ (9 \% ПДФО та $1,5 \%$ військового збору). Ця особливість дає змогу інвесторам спокійно вкладати кошти в такий фонд та виводити їх, не сплачуючи при цьому ніяких податків[9].

На відміну від інших ICI, Закон України «Про інститути спільного інвестування» дозволяє венчурному фондам надавати процентну позику (п. 6 ч. 3 ст.14 Закону). Доходи у вигляді відсотків, отриманих венчурним ICI, не оподатковуватимуться податком на прибуток відповідно по пп.141.6.1 ст.141 ПКУ. В той же час підприємство включає проценти за кредит у витрати, зменшуючи таким чином, оподатковуваний дохід. Таким чином, для венчурних фондів створені податкові преференції щодо сплати податку на прибуток. Цим користуються промислові підприємства, торговельні та будівельні організації як альтернатива банківському кредитуванню.

3 нашої точки зору, більш перспективним $\epsilon$ не звільнення від оподаткування податком на прибуток венчурних фондів, а надання їм пільг. Звільнення від оподаткування або зменшення бази оподаткування може надаватися на величину прибутку, отриманого від реалізованого інноваційного проєкту. Потребує встановлення максимального розміру пільги, тобто максимального зменшення податкової бази при оподаткуванню податком на прибуток. При цьому оподаткуванню податком на прибуток підлягали б операції з державними цінними паперами, місцевими облігаціями, об'єктами нерухомості i т. п. Це дало б змогу, по-перше, збільшити податкові надходження від фінансових операцій; по-друге, зменшити обсягів ухилення від сплати податків підприємствами традиційних секторів економіки, що використовують венчурні фонди як інструмент зменшення оподаткування.

Вказані виклики потребують подальшого удосконалення податкового та правового законодавства, націленого на випереджаючий інноваційний розвиток країни які повинні забезпечити зростання конкурентоздатної інноваційної 
продукції та послуг, прискореної комерціалізації інтелектуальної власності та реалізації науково-технічного потенціалу країни.

В розвинених країнах набув широкого поширення такий інструмент венчурного фінансування, як конвертована позика, що $є$ найбільш поширеним інструментом брідж-фінансування. При наданні таких позик відбувається конвертації позичкових коштів в частку (акції) інноваційної компанії. Надання конвертованих позик дозволяє забезпечити швидке надходження грошових коштів, гарантує забезпечення прав інвесторів, а також дозволяє компенсувати тимчасову нестачу ліквідності. Для венчурного фонду головним інтересом надання конвертованих позик $є$ не повернення коштів, а купівля акцій компанії, курс яких має значні перспективи зростання.

Необхідно зазначити, що укладання угод із конвертації позик характеризує високий рівень розвитку. Нині в Україні він використовується досить рідко. Однією із причин такого становища є законодавча невизначеність даного виду угод, а також особливості корпоративного законодавства. Зокрема, поширення такого виду угод потребує перш за все на законодавчому рівні посилення ступеня захищеності інвесторів, розробку законодавчих актів, що регулюють умови конвертації позики в капітал підприємства, забезпечення зобов'язань компанії перед інвесторами.

Розвиток сформованого в Україні інституту венчурного фінансування i необхідність подолання цілого ряду суттєвих недоліків потребує подальших цілеспрямованих заходів держави, спрямованих на прискорений розвиток інноваційної діяльності. Подальше удосконалення правової та податкової систем в значній мірі буде сприяти розвитку венчурного фінансування як одного із елементів інноваційної країни.

Важливим завданням венчурного фінансування в Україні повинно стати створення необхідних фінансових інструментів підтримки технологічного підприємництва, що здійснюється в пріоритетних напрямках. Венчурні фонди повинні надавати дуже важливу увагу співробітництву з академічною наукою, передусім з університетами. В університетських лабораторіях розробляються високорентабельні технічні проєкти, які можуть бути привабливими для венчурного фінансування. На жаль, сьогодні практично не спостерігається активізації співробітництва венчурних фондів та вищої освіти. Обсяг НДР, виконаних вищою освітою для підприємницького сектору в 2019 р. становив лише 1,1 млрд грн, що становить близько 10 \% від загального обсягу НДР.

Венчурний капітал ще не став ефективним механізмом фінансування інноваційного бізнесу в Україні. Розширене відтворення венчурного капіталу не спрямоване на розвиток національної інноваційно-технологічного підприємства України. Існує нагальна проблема переорієнтації венчурних фондів на фінансування інноваційних проєктів.

Висновки. Отже, в Україні за останні роки сформувався штучний розрив між двома сегментами одного (по суті) інвестиційного ринку, в результаті чого значні обсяги фінансових ресурсів фондів венчурного капіталу використовуються для уникнення оподаткування, диверсифікації ризиків, 
отримання стійкого прибутку на вкладені кошти. Для зростання конкурентоздатності української економіки, стимулювання переходу іiі на інноваційний шлях розвитку доцільно удосконалювати залучення венчурного капіталу, забезпечити переорієнтацію венчурного капіталу на фінансування інноваційної діяльності. 3 цією метою пропонуємо внести зміни до ст. 141.6 Податкового кодексу України та позбавити венчурні фонди преференціями щодо оподаткування податком на прибуток. Більш перспективним напрямом переорієнтації венчурного капіталу на фінансування інноваційних проєктів $\epsilon$ встановлення додаткових податкових стимулів для венчурних інвесторів можуть виступати звільнення від оподаткування або зниження податкової бази на величину прибутку від реалізації інноваційних проєктів. Цей варіант $\epsilon$ менш обтяжливим для бюджету з точки зору неотриманих надходжень, $\mathrm{i}$ в той же час буде сприяти мобілізації ресурсів для фінансування інноваційної діяльності.

\section{Перелік посилань.}

1. Бражник Л. В., Дорошенко О. О. Діяльність інститутів спільного інвестування в України. Інфраструктура ринку. 2020. Вип. 42. С. 279-284.

2. Носова Є. А., Могге Д. Б. Сучасний стан та особливості функціонування венчурних інвестиційних фондів в Україні. Ефективна економіка. 2017. № 3. URL: http://www.economy.nayka.com.ua/?op=1\&z=5491. (дата звернення: 18.09.2021).

3. Третякова О. В., Харабара В. М., Грешко Р. I. Венчурне фінансування як ефективний інструмент інноваційного розвитку України. Інвестииія: практика та досвід. 2020. № 17-18. С. 18-23.

4. Кочура Т. О. Глобальні тренди розвитку венчурного капіталу та їх вплив на інвестування високотехнологічних проєктів. Бізнес-інформ. 2020. № 4. C. $118-126$.

5. Стратегія розвитку сфери інноваційної діяльності на період до 2030 року: розпорядження Кабінету Міністрів України від 10.07.2019 р. № 526-р. URL: https://zakon.rada.gov.ua/laws/show/526-2019-\%D1\%80\#Text (дата звернення: 18.09.2021).

6. Про інститути спільного інвестування: Закон України від 5 липня 2012 p. № 5080-VI. URL: https://zakon.rada.gov.ua/laws/show/5080-17\#Tеxt (дата звернення: 18.09.2021).

7. Податковий кодекс України від 02.12.2010 p. № 2755-VI. URL : http ://sfs. gov.ua/nk. (дата звернення 18.09.2021).

8. Діденко Л. В., Ватоян А. М., Срьоміна М. А. Роль венчурних інститутів спільного інвестування в забезпеченні інноваційного розвитку України. Економіка і суспільство. 2018. Вип. 19. С. 143-151.

9. Стариченко О. Особливості та можливості венчурних інвестиційних фондів в Україні. URL: http://www.ufin.com.ua/analit_mat/rzp/195.htm/ (дата звернення: 18.09.2021).

10. Мордань Є.Ю., Відменко Ю.В., Кобець Ж.О. Венчурне інвестування в Україні та світі: сучасні тенденції та особливості розвитку. Громі, фінанси $i$ кредит. № 17. 2018. С. 391 - 399. 


\section{References}

1. Brazhny`k, L. V., Doroshenko, O. O. (2020). Activities of mutual investment institutions in Ukraine [Diyal'nist` insty 'tutiv spil`nogo investuvannya $\mathrm{v}$ Ukrayiny]. Market infrastructure. № 42. P, 279-284.

2. Nosova, Ye. A., Mogge, D. B. (2017). Current state and features of venture investment funds in Ukraine [Suchasny $\mathrm{j}$ stan ta osobly`vosti funkcionuvannya venchurny`x investy`cijny`x fondiv v Ukrayini]. Efficient economy. № 3, available at: http://www.economy.nayka.com.ua/?op=1\&z=5491 (last accessed 18.09.2021).

3. Tretyakova, O. V., Xarabara, V. M., Greshko, R. I. (2020). Venture financing as an effective tool for innovative development of Ukraine. [Venchurne finansuvannya yak efekty`vny`j instrument innovacijnogo rozvy`tku Ukrayiny]. Investment: practice and experience. № 17-18, P. 18-23.

4. Kochura, T. O. (2020). Global trends in venture capital development and their impact on investing in high-tech projects. [Global'ni trendy' rozvy'tku venchurnogo kapitalu ta yix vply`v na investuvannya vy`sokotexnologichny`x proyektiv]. Business inform. № 4, P. 118-126.

5. Strategy for the development of innovation in the period up to 2030: order of the Cabinet of Ministers of Ukraine dated 10.07.2019 № 526-r. [Strategiya rozvy`tku sfery` innovacijnoyi diyal'nosti na period do 2030 roku: rozporyadzhennya Kabinetu Ministriv Ukrayiny` vid 10.07.2019. 526-r.], available at: https://zakon.rada.gov.ua/laws/ show/ 526-2019-\%D1\%80\#Text (last accessed 18.09.2021).

6. On mutual investment institutions: Law of Ukraine of July 5, 2012 № 5080-VI [Pro insty`tuty` spil`nogo investuvannya]: Zakon Ukrayiny` vid 5 ly`pnya 2012. № 5080-VI, available at: https://zakon.rada.gov.ua/laws/show/5080-17\#Text (last accessed 18.09.2021).

7. Tax Code of Ukraine 2.10.2010 № 2755-VI [Podatkovy`j kodeks Ukrayiny` vid 02.12.2010 r. № 2755-VI], available at: http ://sfs. gov.ua/nk (last accessed 18.09.2021).

8. Didenko, L. V., Vatoyan, A. M., Yer'omina, M. A. (2018). The role of venture capital investment institutions in ensuring the innovative development of Ukraine [Rol` venchurny`x insty`tutiv spil'nogo investuvannya $\mathrm{v}$ zabezpechenni innovacijnogo rozvy’tku Ukrayiny`]. Economy and society № 19, P. 143-151.

9. Stary`chenko O. Features and capabilities of venture investment funds in Ukraine. [Osobly`vosti ta mozhly`vosti venchurny`x investy`cijny`x fondiv v Ukrayini], available at: http://www.ufin.com.ua/analit_mat/rzp/195.htm (last accessed 18.09.2021).

10. Mordan, E.Yu., Vidmenko, Yu.V., Kobets, Zh.O. (2018). Venture investment in Ukraine and the world: current trends and features of development.[Venchurne investuvannya $\mathrm{v}$ Ukrayini ta sviti: suchasni tendenciyi ta osobly`vosti rozvy`tku]. Money, finance and credit. № 17. P. 391-399. 


\section{РЕФЕРАТИ РЕФЕРАТЫ ABSTRACTS}

\section{УДК 338.3; JEL Classification: М9}

\section{Непран А. В., Тимченко І. Є. ВЕНЧУРНИЙ КАПІТАЛ ТА ІННОВАЦІї}

Mema - проаналізувати поточний стан розвитку венчурного капіталу в Україні і запропонувати механізми залучення венчурного капіталу для підвищення конкурентоздатності української економіки. Методика дослідження. Для досягнення поставленої мети у дослідженнях були використані такі загальнонаукові та спеціальні методи і прийоми дослідження: методи узагальнення та абстрагування - для проведення аналізу тверджень законодавчого характеру щодо розвитку венчурного капіталу; відносні показники динаміки і структури. Результати. В сучасних умовах капітал венчурних фондів набув значних розмірів, що дозволяє його розглядати як важливий елемент інноваційної системи країни. Маються значні диспропорції: відмічається недостатній обсяг пропозиції венчурного капіталу для фінансування пріоритетних напрямів інноваційної діяльності. Встановлено, що значна частина капіталу венчурних фондів використовується для купівлі облігацій підприємств, державних та місцевих боргових цінних паперів, надання позики. Ці фінансові операції не пов'язані з інноваційною діяльністю, а використовуються як альтернатива банківському кредитуванню, а також для зниження податкового навантаження. Диспропорції, що сформувалися в національній системі фінансування інновацій не дозволяють повністю розкрити потенціал венчурного фінансування. Для стимулювання конвертованої позики як одного із поширених інструментів венчурного фінансування необхідно на законодавчому рівні посилити ступінь захисту прав інвесторів по відношенню до позичальників. Наукова новизна. Полягає у спростуванні твердження про недостатність фінансових ресурсів для венчурного фінансування, визначення напрямів стимулювання розвитку венчурного капіталу. Практична значущість. Завдяки впровадженню розроблених заходів в перспективі можна забезпечити переорієнтацію капіталу венчурних фондів на фінансування інноваційних проєктів, що забезпечить становлення інноваційних компаній та перетворення їх у конкурентоздатні підприємства.

Ключові слова: інвестування, венчурний капітал, інновації, інноваційні венчурні фонди, фінансовий ризик, венчурні підрозділи компаній.

\section{УДК 338.3; JEL Classification: М9}

Непран А. В., Тимченко И. Е. ВЕНЧУРНЫЙ КАПИТАЛ И ИННОВАЦИИ

Цель - проанализировать текущее состояние развития венчурного капитала в Украине и предложить механизмы привлечения венчурного капитала для повышения конкурентоспособности украинской экономики. Методика исследования. Для достижения поставленной цели в исследованиях были использованы такие общенаучные и специальные методы и приемы исследования: методы обобщения и абстрагирования — для проведения 
анализа утверждений законодательного характера по развитию венчурного капитала; относительные показатели динамики и структуры. Pезультаты. В современных условиях капитал венчурных фондов приобрел внушительных размеров, что позволяет его рассматривать как важный элемент инновационной системы страны. Имеются значительные диспропорции: отмечается недостаточный объем предложения венчурного капитала для финансирования приоритетных направлений инновационной деятельности. Установлено, что значительная часть капитала венчурных фондов используется для покупки облигаций предприятий, государственных и местных долговых ценных бумаг, предоставление займа. Эти финансовые операции не связаны с инновационной деятельностью, а используются как альтернатива банковскому кредитованию, а также для снижения налоговой нагрузки. Диспропорции, сформировавшиеся в национальной системе финансирования инноваций не позволяют полностью раскрыть потенциал венчурного финансирования. Для стимулирования конвертируемой займа как одного из распространенных инструментов венчурного финансирования необходимо на законодательном уровне усилить степень защиты прав инвесторов по отношению к заемщикам. Научная новизна. Состоит в опровержении утверждения о недостаточности финансовых ресурсов для венчурного финансирования, определения направлений стимулирования развития венчурного капитала. Практическая значимость. Благодаря внедрению разработанных мероприятий в перспективе можно обеспечить переориентацию капитала венчурных фондов для финансирования инновационных проектов, обеспечит становление инновационных компаний и превращение их в конкурентоспособные предприятия.

Ключевые слова: инвестирование, венчурный капитал, инновации, инновационные венчурные фонды, финансовый риск, венчурные подразделения компаний.

\section{UDK 338.3; JEL Classification: M9}

\section{Nepran AV, Timchenko IE VENTURE CAPITAL AND INNOVATION}

Purpose - to analyze the current state of venture capital development in Ukraine and propose mechanisms to attract venture capital to increase the competitiveness of the Ukrainian economy. Methodology of research. To achieve this goal, the following general scientific and special research methods and techniques were used in the research: methods of generalization and abstraction - to analyze the allegations of a legislative nature for the development of venture capital; relative indicators of dynamics and structure. Findings. In modern conditions, the capital of venture funds has acquired an impressive size, which allows it to be considered as an important element of the country's innovation system. There are significant imbalances: there is an insufficient supply of venture capital to finance priority areas of innovation. It is established that a significant part of the capital of venture funds is used for the purchase of corporate bonds, government and local debt securities, the provision of loans. These financial transactions are not related to innovation, but are used as an alternative to bank lending, as well as to reduce the tax burden. The imbalances that have formed in the national system of financing 
innovation do not allow the full potential of venture financing to be unleashed. To stimulate a convertible loan as one of the common instruments of venture financing, it is necessary at the legislative level to strengthen the degree of protection of the rights of investors in relation to borrowers. Originality. It consists in refuting the statement about the insufficiency of financial resources for venture financing, determining the directions of stimulating the development of venture capital. Practical value. Thanks to the implementation of the developed measures in the future it is possible to ensure the reorientation of the capital of venture funds to finance innovative projects, will ensure the formation of innovative companies and their transformation into competitive enterprises.

Key words: investment, venture capital, innovations, innovative venture funds, financial risk, venture divisions of companies.

\section{Відомості про авторів / Сведения об авторах / About the Authors}

Непран Андрій Володимирович - канд. екон. наук, доцент, Харківський національний автомобільно-дорожній університет, доцент кафедри економіки i підприємництва, м. Харків, Україна; е-mail: nepranxtei@gmail.com; ORCID ID: https://orcid.org/0000-0002-8329-7123. Моб. 097-546-01-22.

Непран Андрей Владимирович - кандидат экономических наук, доцент, Харьковский национальный автомобильно-дорожный университет, доцент кафедры экономики и предпринимательства, г. Харьков, Украина.

Nepran Andrey - Candidate of Science (Economics), Associate Professor, Kharkiv National Automobile and Highway University, Associate Professor, Department of Economics and Entrepreneurship, Kharkiv, Ukraine.

Тимченко Ірина Свгеніївна - канд. екон. наук, доцент, Харківський університет, доцент кафедри фінансів, обліку і аудиту. м. Харків, Україна; еmail: nepranxtei@gmail.com. Моб. 050-183-89-60.

Тимченко Ирина Евгеньевна - кандидат экономических наук, доцент, Харьковский университет, доцент кафедры финансов, учета и аудита, г. Харьков, Украина;

Timchenko Irina - Candidate of Science (Economics), Associate Professor, Kharkiv University, Associate Professor, Department of Financial, Accounting and Auditing, Kharkiv, Ukraine. 